\title{
PEMBUDAYAAN PENGELOLAAN KEUANGAN BERBASIS AKUNTANSI BAGI PELAKU USAHA KECIL MENENGAH
}

\author{
Zarah Puspitaningtyas \\ Universitas Jember, Jember, \\ Email: zarah@unej.ac.id
}

\begin{abstract}
The problems faced by small and medium enterprises (SMEs), one of which is lack of ability in business finance management. Businesses often feel confined in their ability to apply accounting because they are not yet accustomed to practicing accounting in the management of their business finances. The solution of these problems, then the businesses needs to get training and assistance in a sustainable manner related to the financial management of accounting-based business, so as to manage their business finances effectively. The purpose of this study is to know the culture of accounting-based financial management for businesses "batik" sector in Banyuwangi. The analysis was done by qualitative descriptive method, that is basing the result of observation and interview with informant. The results of the analysis concluded that accounting-based financial management can provide benefits for businesses to know the exact financial condition of the business, regulate and control the overall financial transactions that occur along the sustainability of its business. Therefore, businesses should familiarize (cultivate) to implement accounting-based financial management. The implication of the result of this study is expected to be composed of concepts related to the culture of accounting-based financial management for businesses actors, especially SMEs.
\end{abstract}

Keywords: financial management, accounting, SMEs

\begin{abstract}
Abstrak: Permasalahan yang dihadapi pelaku usaha kecil dan menengah (UKM), salah satunya adalah kurang memiliki kemampuan dalam pengelolaan keuangan usaha. Pelaku UKM seringkali merasa terkungkung dalam kemampuan mereka menerapkan akuntansi karena belum terbiasa mempraktekkan akuntansi dalam pengelolaan keuangan usahanya. Solusi dari permasalahan tersebut, maka pelaku UKM perlu mendapatkan pelatihan dan pendampingan secara berkelanjutan berkaitan dengan pengelolaan keuangan usaha berbasis akuntansi, sehingga dapat mengelola keuangan usahanya secara efektif. Tujuan studi ini adalah untuk mengetahui pembudayaan pengelolaan keuangan berbasis akuntansi bagi pelaku UKM sektor batik di Banyuwangi. Analisis dilakukan dengan metode deskriptif kualitatif, yaitu mendasarkan hasil observasi dan interview dengan informan. Hasil analisis menyimpulkan bahwa pengelolaan keuangan berbasis akuntansi dapat memberikan manfaat bagi pelaku UKM untuk mengetahui kondisi keuangan usaha secara pasti, mengatur dan mengontrol keseluruhan transaksi keuangan yang terjadi di sepanjang keberlangsungan usahanya. Oleh karena itu, pelaku UKM harus membiasakan (membudayakan) untuk menerapkan pengelolaan keuangan berbasis akuntansi. Implikasi dari hasil studi ini adalah diharapkan dapat tersusun konsep yang berkaitan dengan pembudayaan pengelolaan keuangan berbasis akuntansi bagi pelaku usaha, khususnya pelaku UKM.
\end{abstract}

Kata Kunci: pengelolaan keuangan, akuntansi, UKM 


\section{PENDAHULUAN}

Perkembangan usaha kecil dan menengah (UKM) dengan semangat meningkatkan kemandirian secara ekonomi telah memberikan dampak positif pada peguatan perekonomian lokal. Akan tetapi, terdapat beberapa permasalahan yang dihadapi pelaku UKM, salah satunya adalah kurang memiliki kemampuan dalam pengelolaan keuangan usaha. Beberapa pelaku UKM cenderung tidak melakukan pemisahan antara keuangan keluarga dan keuangan usaha. Akibatnya, seringkali keuangan usaha terpakai untuk memenuhi kebutuhan keluarga sehari-hari. Pelaku UKM seringkali merasa terkungkung dalam kemampuan mereka menerapkan akuntansi karena belum terbiasa mempraktekkan akuntansi dalam pengelolaan keuangan usahanya (Maseko dan Manyani, 2011; Lohr, 2012; Aurora, 2013; Turyahebwa et al., 2013; Puspitaningtyas, 2015b).

Solusi dari permasalahan tersebut, maka pelaku UKM perlu mendapatkan pendidikan dan pelatihan secara berkelanjutan berkaitan dengan pengelolaan keuangan usaha secara efektif. Bagaimana cara melakukan pengelolaan usaha secara efektif? Agar dapat menerapkan pengelolaan keuangan usaha secara efektif, maka penting bagi pelaku UKMuntuk memahami manfaat akuntansi bagi keberlanjutan bisnis. Salah satu manfaat dari penerapan pengelolaan keuangan berbasis akuntansi adalah peluang untuk mendapatkan pembiayaan dari lembaga keuangan dalam rangka meningkatkan nilai tambah dan produktivitas usahanya.

Upaya peningkatan kompetensi pengelolaan keuangan usaha bagi pelaku UKM telah dilakukan oleh pemerintah melalui Dinas Koperasi dan Usaha Mikro, Kecil, dan Menengah (UMKM). Akan tetapi, pada kenyataannya beberapa pelaku usaha (khususnya pelaku UKM) cenderung belum memiliki kemampuan untuk mengimplementasikan akuntansi dalam pengelolaan keuangan usahanya. Oleh karena itu, perlu dilakukan upaya untuk menumbuhkan kebiasaan (pembudayaan) bagi pelaku usaha sehingga memiliki kemauan dan kemampuan mengelola keuangan usahanya dengan berbasis pada fungsifungsi akuntansi (yaitu: pencatatan, pengidentifikasian, pengukuran, pelaporan, dan pengambilan keputusan).

Seberapa penting akuntansi diterapkan dalam pengelolaan keuangan usaha? Pengelolaan keuangan usaha berbasis akuntansi sangat penting untuk diterapkan. Pada dasarnya, setiap kegiatan usaha yang didalamnya terdapat transaksi keuangan perlu menerapkan pencatatan akuntansi. Penerapan pencatatan akuntansi akan membuat pelaku usaha dapat mengetahui kondisi keuangan usahanya (misalnya, dapat mengetahui arus kas usahanya, dapat mengetahui pendapatan usahanya, dapat mengetahui beban-beban usahanya). Namun, beberapa pelaku UKM belum memahami manfaat akuntansi tersebut, sehingga belum menerapkan akuntansi dalam pengelolaan keuangan usahanya. Pelaku UKM cenderung beranggapan bahwa proses akuntansi memerlukan waktu dan biaya yang tidak sedikit dan tidak berimbang dengan manfaat yang akan diperoleh (Maseko dan Manyani, 2011; Rudiantoro dan Siregar, 2011; Apak et al., 2012; Puspitaningtyas, 2013a).

Berdasarkan uraian tersebut, studi ini bermaksud untuk mengetahui pembudayaan pengelolaan keuangan berbasis akuntansi bagi pelaku UKM sektor batik di Banyuwangi. Analisis dilakukan dengan metode deskriptif kualitatif, yaitu mendasarkan hasil observasi dan interview dengan informan. Implikasi dari hasil studi ini adalah diharapkan dapat tersusun konsep yang berkaitan dengan pembudayaan pengelolaan keuangan berbasis akuntansi bagi pelaku usaha, khususnya pelaku UKM. 


\section{KAJIAN TEORI}

Akuntansi dan Manfaatnya bagi Pelaku Usaha. Akuntansi merupakan suatu proses pencatatan transaksi yang berkaitan dengan kegiatan ekonomi sehingga tersaji informasi keuangan yang bermanfaat bagi pihak-pihak yang berkepentingan, baik pihak internal maupun pihak eksternal, dalam rangka pengambilan keputusan. Informasi keuangan tersebut menjadi media komunikasi bagi pihak-pihak yang berkepentingan untuk menilai kinerja suatu usaha pada suatu periode, sehingga memiliki kemungkinan untuk memilih alternatif yang terbaik di antara berbagai alternatif yang dipertimbangkan di bawah kondisi ketidakpastian (uncertainty). Pelaku usaha sebagai pengguna informasi akuntansi seharusnya mengetahui dan memahami apa yang mereka butuhkan, dengan pertimbangkan biaya yang rasional (Chiou, 2011; Denisa, 2012; Puspitaningtyas, 2012).

Bagi pihak internal, akuntansi dapat memberikan manfaat sebagai berikut: sebagai alat pengendalian atau pengontrolan keuangan, sebagai alat evaluasi, dan sebagai alat untuk menyusun perencanaan usaha di masa depan. Informasi yang tersaji dari proses akuntansi akan menunjukkan kondisi keuangan usaha pada suatu periode, apakah dalam kondisi mendapatkan keuntungan atau mengalami kerugian. Berdasarkan informasi akuntansi, pelaku usaha dapat melakukan evaluasi atas kinerja usahanya untuk dapat melakukan identifikasi berbagai masalah keuangan yang dihadapi. Selanjutnya, berdasarkan hasil evaluasi, pelaku usaha dapat menyusun perencanaan usaha yang akan dilakukan pada periode mendatang.

Bagi pihak eksternal, manfaat akuntansi adalah untuk memberikan informasi yang berkaitan dengan performa atau kinerja suatu usaha. Berdasarkan informasi tersebut akan dapat dilakukan pengambilan keputusan, misalnya bagi pihak perbankan akan dapat melakukan pengambilan keputusan untuk memberikan kredit (pinjaman dana). Dengan mengetahui kondisi keuangan usaha maka akan memberikan peluang bagi suatu usaha untuk mendapatkan pembiayaan dari pihak eksternal. Berdasarkan informasi akuntansi yang tersaji, pelaku usaha dapat memberikan keyakinan kepada pihak eksternal (perbankan atau kreditur) bahwa usaha yang dijalankan dapat menguntungkan dan pembiayaan yang diberikan dapat dipertanggungjawabkan. Jadi, secara garis besar manfaat akuntansi bagi pelaku usaha adalah sebagai alat untuk pengambilan keputusan.

Informasi keuangan yang dihasilkan dari proses akuntansi menjadi indikator keberhasilan (kinerja) usaha. Informasi tersebut dapat bermanfaat untuk pengambilan keputusan bisnis. Pemanfaatan informasi akuntansi untuk pengambilan keputusan akan mendukung ketepatan pelaku usaha dalam mempertimbangkan berbagai alternatif atas keputusan yang diambil. Manfaat akuntansi dan kebutuhan informasi akuntansi memberikan kontrbusi yang cukup signifikan terhadap keinginan pelaku usaha untuk menggunakan informasi akuntansi dalam pengembangan dan keberlanjutan usahanya dalam jangka panjang (Hira, 2009; Astuti, 2010; Ediraras, 2010; Puspitaningtyas, 2012; Putra dan Kurniawati, 2012; Salazar et al., 2012; Schaltengger et al., 2012; Karina, 2014; Williams dan O'Donovan, 2015).

Penerapan akuntansi dan pengambilan keputusan yang didasarkan pada pertimbangan informasi akuntansi mengindikasikan kemampuan pelaku usaha dalam memahami pengetahuan keuangan yang dimiliki. Hal tersebut didukung oleh pernyataan bahwa pengetahuan keuangan berpengaruh terhadap perilaku keuangan yang mencerminkan tanggung jawab pelaku usaha dalam mengelola keuangan usaha (Arifin et al., 2017; Puspitaningtyas, 2017; Suryani et al., 2017). 
Pengelolaan Keuangan Berbasis Akuntansi. Pengelolaan keuangan yang baik akan berpengaruh pada peningkatan kinerja usaha dan peningkatan daya saing. Pada umumnya, pengelolaan keuangan UKM berjalan tanpa mengandalkan informasi akuntansi yang disusun secara terstruktur. Pelaku UKM merasa belum memerlukan penerapan akuntansi dalam pengelolaan keuangan usahanya. Keputusan yang diambil tidak didasarkan pada informasi akuntansi, akan tetapi cenderung didasarkan pada intuisi atau kebiasaan yang berasal pengalaman di masa lalu. Akibatnya, pelaku UKM tidak dapat mengetahui kondisi keuangan secara tepat, seperti: berapa pendapatan yang diperoleh pada setiap periode, berapa biaya-biaya yang dikeluarkan pada setiap periode, apakah usahanya mendapatkan keuntungan atau mengalami kerugian. Perencanaan usaha tidak disusun berdasarkan evaluasi kinerja keuangan, sehingga alokasi dana menjadi kurang tepat. Biasanya, permasalahan tersebut akan semakin kompleks seiring dengan semakin berkembangnya kegiatan usaha (Laurinkeviciute dan Stasiskiene, 2011; Maseko dan Manyani, 2011; Young et al., 2012; Turyahebwa et al., 2013; Kaveh et al., 2015; Puspitaningtyas, 2013b; 2016).

Bagaimana pengelolaan keuangan berbasis akuntansi? Sebagai langkah awal, pelaku usaha harus memahami proses pencatatan akuntansi hingga dapat tersaji laporan keuangan. Proses akuntansi berawal dari pencatatan transaksi, pengklasifikasian atau penggolongan, pelaporan, dan penganalisaan informasi keuangan. Proses akuntansi tersebut mencerminkan fungsi akutansi, yaitu: mengidentifikasi transaksi sehingga dapat tersaji data keuangan yang relevan, menganalisa data yang telah tersaji, mengolah data menjadi suatu informasi yang handal dan bermanfaat untuk pengambilan keputusan bagi pelaku usaha.

Informasi keuangan atau akuntansi yang dimaksud adalah segala catatan terkait dengan transaksi keuangan yang terjadi pada usaha yang dijalankan, yaitu catatan atas penjualan, piutang, utang, persediaan, biaya-biaya, dan lainnya. Selanjutnya, catatancatatan tersebut seharusnya tersaji pada laporan keuangan yang terdiri dari neraca, laporan laba rugi, perubahan posisi modal, dan arus kas. Informasi yang tersaji dalam laporan keuangan mencerminkan kondisi keuangan usaha pada suatu periode. Kim et al. (2011) menyebutkan bahwa terhadap hubungan antara akuntansi dan dokumen keuangan. Artinya, setiap pencatatan harus disertai bukti (dokumen) transaksi sebagai lampiran.

Agar laporan keuangan dapat menggambarkan kondisi keuangan, maka perlu dilakukan analisis dengan menghubungkan atau membandingkan di antara akun-akun yang tersaji pada laporan keuangan. Misalnya, menghubungkan atau membandingkan akun utang lancar dan akun aktiva lancar, dari hasil perbandingan tersebut akan dapat diketahui kemampuan usaha dalam melunasi utang lancarnya (current ratio). Menghubungkan atau membandingkan akun laba bersih dan akun penjualan, sehingga diketahui besarnya kontribusi penjualan terhadap laba usaha (Puspitaningtyas, 2015a).

Penerapan Akuntansi bagi Pelaku Usaha. Banyak pelaku UKM yang belum menyadari bahwa penerapan akuntansi merupakan salah satu aspek untuk menciptakan usaha yang sehat dan tangguh dari sisi keuangan. Segala transaksi keuangan yang terjadi harus dicatat dengan terstruktur dan tersistematis disertai dengan bukti transaksi untuk laporan usaha. Karena, masih banyaknya pelaku UKM yang belum menerapkan akuntansi pada pengelolaan keuangan usahanya maka peran pemerintah akan sangat penting bagi pelaku usaha untuk memberikan pelatihan, pemahaman, dan pendampingan dalam rangka pembudayaan (pembiasaan diri) dalam penerapan akuntansi. 
Merujuk pada hasil studi oleh Inn et al. (2015) yang menyatakan bahwa pemerintah dalam menjalankan perannya harus benar-benar mampu memposisikan diri sebagai pendidik atau pelatih, bukan sekadar menjalankan pekerjaan atau tugas. Oleh karena itu, penting bagi pelaku usaha untuk diberikan pelatihan pengelolaan keuangan, pemahaman akan pentingnya penerapan akuntansi, serta pendampingan tentang bagaimana cara mempraktekkan pencatatan akuntansi dan pembuatan laporan keuangan yang baik secara berkelanjutan, sehingga pelaku usaha akan menjadi terbiasa menerapkan akuntansi dalam pengelolaan keuangan usahanya. Pencatatan akuntansi yang dilakukan secara terstruktur dan tersistematis, akan bermanfaat bagi pelaku usaha untuk mengetahui kondisi keuangan usaha secara pasti.

Pelaku UKM seringkali beranggapan bahwa akuntansi kurang bermanfaat bagi usahanya, sehingga atas transaksi keuangan yang terjadi tidak dilakukan pencatatan, bukti transaksi yang seharusnya menjadi lampiran dalam penerapan akuntansi juga diabaikan, akibatnya usaha yang dijalankan menjadi tidak berkembang. Pelaku UKM beranggapan bahwa akuntansi hanya dibutuhkan untuk usaha besar. Pelaku UKM seharusnya memahami bahwa usaha sebesar apapun, akan sangat memerlukan akuntansi jika menginginkan usaha yang dijalankan dapat berkembang. Karena, sesederhana apapun transaksi usaha yang terjadi, informasi yang dihasilkan dari proses penerapan akuntansi akan memberikan manfaat yang relevan bagi keberlanjutan usaha.

\section{METODE}

Analisis dalam studi ini dilakukan dengan menggunakan metode deskriptif kualitatif, yaitu mendasarkan pada hasil observasi dan interview dengan informan. Tiga pelaku usaha pada sektor batik di Banyuwangi menjadi informan dalam studi ini, yaitu informan A, informan B, dan informan C. Ketiga informan tersebut telah mendapatkan pelatihan dan pendampingan pengelolaan keuangan usaha berbasis akuntansi yang diselenggarakan oleh Dinas Koperasi dan UMKM Kabupaten Banyuwangi. Selain itu, interview juga dilakukan dengan informan dari pihak Dinas Koperasi dan UMKM Kabupaten Banyuwangi (informan D). Interview dilakukan dengan menggunakan panduan wawancara yang berkaitan dengan pertanyaan dan pernyataan tentang strategi pembudayaan pengelolaan keuangan berbasis akuntansi bagi pelaku usaha, khususnya UKM.

\section{HASIL DAN PEMBAHASAN}

Pembudayaan Pengelolaan Keuangan Berbasis Akuntansi. Informasi akuntansi memiliki peran penting dalam mencapai keberhasilan suatu usaha, baik pada usaha besar maupun usaha kecil. Informasi akuntansi dapat menjadi dasar bagi pengambilan keputusan bisnis. Akan tetapi, penerapan akuntansi dalam pengelolaan keuangan UKM masih cenderung rendah. Bagi sebagian besar pelaku UKM, tidak dilakukannya penerapan akuntansi dalam pengelolaan keuangan usahanya karena merasa tidak membutuhkan informasi akuntansi. Meskipun mereka telah mengetahui manfaat yang akan diperoleh dari penerapan akuntansi, akan tetapi cenderung belum ada kemauan dan kemampuan untuk menerapkan akuntansi dalam pengelolaan keuangan usahanya. Mereka cenderung beranggapan bahwa akuntansi adalah sesuatu yang sulit dan rumit untuk diterapkan (hasil wawancara dengan informan A, informan B, dan informan C). Oleh karena itu, diperlukan upaya-upaya untuk membudayakan pengelolaan keuangan berbasis akuntansi bagi pelaku 
usaha, khususnya bagi pelaku UKM. Salah satu upaya yang dilakukan pemerintah melalui Dinas Koperasi dan UMKM adalah melaksanakan program pelatihan dan pendampingan pengelolaan keuangan usaha berbasis akuntansi.

Bagaimana strategi pembudayaan pengelolaan keuangan berbasis akuntansi bagi pelaku usaha? Istilah pembudayaan dimaksudkan sebagai proses atau cara pembiasaan diri untuk melakukan sesuatu tindakan. Pembudayaan pengelolaan keuangan berbasis akuntansi bertujuan untuk mendorong atau memotivasi pelaku UKM untuk membiasakan diri berpikir dan bertindak berdasarkan fungsi akuntansi dalam pengelolaan keuangan usahanya. Strategi pembudayaan tersebut, antara lain dapat dilakukan melalui program pelatihan manajemen keuangan dan pelatihan akuntansi (berkaitan dengan praktek penerapan akuntansi dalam pengelolaan keuangan usaha, baik secara manual maupun terkompurisasi). Selain itu, program pelatihan tersebut harus dilanjutkan dengan program pendampingan. Diharapkan program pelatihan dan pendampingan tersebut dapat dilaksanakan secara berkelanjutan, sehingga mampu mendorong atau memotivasi pelaku UKM untuk membiasakan diri mengelola keuangan usahanya secara baik dan melakukan pencatatan atas transaksi keuangan usahanya secara sistematis (hasil observasi).

Berikut adalah hasil wawancara dengan informan yang menyatakan tentang tujuan dan manfaat dari pelaksanaan program pelatihan dan pengelolaan keuangan usaha berbasis akuntansi: "Tujuan dari pelatihan dan pendampingan pengelolaan keuangan usaha berbasis akuntansi adalah diharapkan pelaku UKM akan terbiasa melakukan pencatatan akuntansi secara sederhana sesuai dengan kebutuhan operasional usahanya dan membuat laporan keuangan usahanya secara periodik. Salah satu manfaat yang dapat diperoleh pelaku UKM melalui pencatatan akuntansi yang baik adalah kemudahan untuk mendapat pembiayaan dari lembaga keuangan sebagai upaya untuk meningkatkan nilai tambah dan produktivitas usaha."(hasil wawancara dengan infoman D).

"Pihak perbankan mewajibkan pelaku usaha untuk memenuhi persyaratan penyajian laporan keuangan sebagai dasar untuk memberikan pinjaman modal. Dimana dengan pinjaman modal, pelaku usaha dapat meningkatkan nilai tambah dan produktivitas usahanya. Oleh karena itu, penting bagi pelaku usaha untuk menerapkan akuntansi dalam pengelolaaan keuangan usahanya. Berdasarkan pada pentingnya penerapan akuntansi maka Dinas Koperasi dan UMKM melaksanakan program kegiatan pelatihan berkaitan dengan pengelolaan keuangan usaha dan pelatihan akuntansi secara berkelanjutan, serta dilanjutkan dengan pendampingan sehingga pelaku usaha menjadi terbiasa untuk menerapkan akuntansi dalam pengelolaan keuangan usahanya." (hasil wawancara dengan informan D).

Berdasarkan hasil observasi, beberapa pelaku UKM sektor batik di Kabupaten Banyuwangi meskipun cenderung tidak melakukan pemisahan keuangan usaha dan keuangan pribadi secara jelas, namun telah melakukan pencatatan atas transaksi usahanya secara sederhana, yaitu pencatatan transaksi pada buku kas berkaitan dengan kas masuk (pemasukan) dan kas keluar (pengeluaran). Namun, pencatatan tersebut dinilai kurang memadai karena belum mampu menyajikan informasi atas kondisi keuangan usaha secara menyeluruh. Seharusnya, pelaku UKM tersebut melakukan pencatatan tidak hanya pada buku kas, akan tetapi juga digolongkan dalam buku besar dan dilakukan penjurnalan, seperti pencatatan pada jurnal penjualan, jurnal pembelian bahan baku, dan sebagainya sesuai dengan transaksi yang terjadi sehingga dapat dilanjutkan pada penyusunan laporan keuangan dan dapat menyajikan informasi yang mencerminkan kinerja keuangan usaha. 
Demi meningkatkan nilai tambah dan produktivitas usahanya, pelaku usaha harus memiliki pengetahuan pengelolaan keuangan usaha berbasis akuntansi, serta memiliki kemauan dan kemampuan untuk menerapkan pengetahuan pengelolaan keuangan berbasis akuntansi yang dimiliki untuk menjalankan usahanya. Berdasarkan hasil dari penerapan akuntansi dalam pengelolaan keuangan usahanya, pelaku usaha dapat melakukan pengambilan keputusan bisnis secara tepat sesuai dengan kondisi keuangan usahanya. Berdasarkan hasil interview, ketiga informan menyatakan bahwa mereka mengetahui dan memahami manfaat dari penerapan akuntansi dalam pengelolaan keuangan usaha, akan tetapi masih diperlukan dorongan (motivasi) untuk memunculkan kemauan menerapkan (mempraktekkan) pengetahuan tersebut secara konsisten, sehingga mereka akan mampu membuat keputusan keuangan yang tepat, yang nantinya akan memberikan implikasi pada kesejahteraannya dalam jangka panjang. Berkaitan dengan pembudayaan pengelolaan keuangan berbasis akuntansi, berikut adalah hasil interview dengan informan.

"Pada mulanya pengelolaan keuangan usaha yang saya lakukan masih kacau, masih belum memiliki manajemen yang tertata rapi. Keuangan usaha dan keuangan pribadi belum terpisah secara jelas. Akibatnya, pada saat itu usaha yang saya lakukan tidak dapat berkembang. Ketika usaha saya mendapat pesanan (order) yang cukup banyak dan membutuhkan tambahan biaya modal, saya kesulitan untuk memperoleh bantuan pinjaman, karena pihak bank meminta informasi laporan keuangan. Pada saat itu saya bukannya tidak mengetahui pentingnya pencatatan akuntansi, akan tetapi saya masih merasa enggan untuk mempraktekkan akuntansi pada usaha yang saya jalankan, padahal sebelumnya saya sudah beberapa kali mengikuti pelatihan pengelolaan keuangan yang diselenggarakan oleh Dinas Koperasi. Saya juga beberapa kali mengikuti pendampingan, akan tetapi ketika program pendampingan telah berakhir, saya kembali malas untuk melanjutkan pencatatan akuntansi atas transaksi usaha secara rapi. Namun, karena pada saat itu saya sangat membutuhkan tambahan modal, maka saya mencoba kembali untuk melakukan pencatatan akuntansi hingga tersedia laporan keuangan secara sederhana. Setelah dianalisis oleh pihak bank, maka pinjaman dana diberikan. Sejak saat itu hingga saat ini saya menjadi terbiasa melakukan pencatatan akuntansi, saya menjadi lebih mudah mengetahui kondisi keuangan usaha. Selain itu, saya menjadi bisa mengukur kemampuan saya untuk mengembangkan usaha. Harapannya saya program pelatihan dan pendampingan tetap diselenggarakan supaya saya bisa mendapatkan tambahan pengetahuan" (hasil wawancara dengan informan A).

"Bekal pengetahuan keuangan tentang teori-teori dan konsep-konsep keuangan saya peroleh di bangku kuliah. Namun dari sisi praktek, saya bisa lebih memahami pengetahuan tentang pengelolaan keuangan setelah mengikuti beberapa kali pelatihan manajemen keuangan dan akuntansi, juga pendampingan praktek akuntansi dari Dinas Koperasi. Awal mula saya mempraktekkan akuntansi, ketika akan mengambil keputusan pinjam modal di bank. Saat itu saya harus mengetahui kondisi keuangan saya, saya juga harus bisa mengukur kemampuan usaha saya untuk membayar cicilan pinjaman. Pencatatan akuntansi yang saya lakukan mungkin tergolong sederhana, saya sesuaikan dengan kebutuhan usaha. Dengan melakukan pencatatan keuangan (akuntansi) saya bisa mengetahui kondisi keuangan usaha. Keputusan usaha yang saya ambil juga saya berdasarkan catatan atau laporan keuangan usaha. Setiap saat saya bisa memantau arus kas usaha, saya berusaha agar pemasukan lebih besar dari pada pengeluaran. Saya juga bisa menghemat biaya-biaya yang seharusnya tidak perlu dikeluarkan. Meskipun awalnya terasa sulit dan rumit, namun karena sudah terbiasa maka tidak ada lagi kata sulit. Semua 
ini saya lakukan agar usaha yang saya jalankan bisa berkembang dan bertahan hingga nanti. Semoga kegiatan pelatihan dan pendampingan pengelolaan bisa tetap ada dan bisa saya ikuti, sehingga saya bisa belajar tentang perkembangan pengelolaan keuangan" (hasil wawancara dengan informan B).

"Karena usaha saya masih kecil maka saat itu saya berpikir, bahwa pencatatan keuangan cukup hanya ditulis pada secarik kertas atau bahkan cukup diingat saja dalam pikiran, sehingga belum perlu melakukan pembukuan (akuntansi). Saya berpikir bahwa yang membutuhkan akuntansi hanya usaha yang sudah besar, yang membutuhkan pengelolaan yang kompleks. Lalu, pada saat mengikuti pelatihan di Dinas Koperasi, saya mendapatkan pemahaman baru, bahwa sebagai pelaku usaha tentunya kita berharap suatu saat usaha kita bisa berkembang lebih besar, omset besar, dan menghasilkan keuntungan yang besar, serta mampu menjangkau pangsa pasar yang luas. Untuk mencapai itu diperlukan modal yang tidak sedikit, karena usaha kita akan dapat berjalan jika ada uang (modal). Uang (modal) yang kita miliki selanjutnya dikelola untuk dapat menghasilkan keuntungan. Berawal dari sinilah, saya menyadari bahwa akuntansi diperlukan dalam pengelolaan keuangan. Pencatatan akuntansi yang saya lakukan mungkin bisa dikatakan sangat sederhana, tapi saya juga memisahkan transaksi-transaksi dalam buku besar. Saya jadi bisa mengetahui berapa besar pendapatan usaha, berapa bahan baku yang yang masih tersedia, dan sebagainya. Berdasarkan pencatatan-pencatatan itu, saya bisa menyusun laporan keuangan (meskipun sederhana). Saya jadi mengetahui pemasukan dan pengeluaran kas usaha, mengetahui secara pasti keuntungan usaha yang saya dapatkan. Lebih dari itu, saya bisa merencanakan untuk memperbesar usaha saya, karena bisa mendapatkan pinjaman lunak dari bank. Saya juga berharap kegiatan pelatihan dan pendampingan praktek akuntansi dapat dilanjutkan, terutama untuk praktek dengan program komputer" (hasil wawancara dengan informan C).

Berdasarkan hasil interview tersebut mengindikasikan bahwa pelaku UKM tidak cukup hanya dengan memiliki pengetahuan yang berkaitan dengan prinsip-prinsip pengelolaan keuangan berbasis akuntansi, akan tetapi juga penting untuk mampu memahami dan memiliki kemauan untuk menerapkan (mempraktekkan) pengetahuan pengelolaan keuangan berbasis akuntansi yang dimiliki. Pengetahuan pengelolaan keuangan berbasis akuntansi yang dimiliki diharapkan akan mampu menuntun pelaku UKM untuk mengambil keputusan bisnis secara tepat berdasarkan berbagai alternatif pertimbangan berdasarkan kondisi keuangan usahanya. Selain itu, dengan berbekal pengalaman dalam penerapan pengetahuan pengelolaan keuangan berbasis akuntansi maka pelaku UKM diharapkan memiliki keunggulan dalam persaingan bisnis dan mampu menjaga keberlanjutan usahanya. Hasil tersebut juga mendukung beberapa hasil studi terdahulu yang mengungkapkan bahwa pengelolaan keuangan berbasis akuntansi memberikan manfaat bagi pelaku usaha, diantaranya sebagai berikut.

Pinasti (2007) menyebutkan bahwa penerapan akuntansi secara empiris terbukti memberikan manfaat bagi pelaku usaha dalam menjalankan usahanya. Ketika pelaku usaha telah menerapkan akuntansi dan merasakan manfaatnya maka akan menganggap bahwa akuntansi penting dalam pengelolaan keuangan usaha. Sebaliknya, ketika pelaku usaha belum mencoba untuk menerapkan akuntansi, maka akan cenderung menganggap akuntansi adalah hal yang sulit dan tidak penting untuk dilakukan, serta tidak memberikan manfaat bagi usahanya.

Maseko dan Manyani (2011) mengungkapkan bahwa mayoritas pelaku UKM tidak melakukan pencatatan akuntansi secara lengkap. Hal tersebut dikarenakan kurangnya 
pengetahuan akuntansi, sehingga berakibat pada tidak efisiennya penggunaan informasi dalam pengukuran kinerja keuangan. Studi ini merekomendasikan agar pemerintah mengembangkan pedoman akuntansi khusus bagi UKM dan mengembangkan program pelatihan akuntansi bagi pelaku UKM. Selain itu, studi ini juga merekomendasikan pencatatan akuntansi wajib untuk dilakukan sehingga dapat memperbaiki praktek akuntansi UKM.

Rudiantoro dan Siregar (2011) menyatakan bahwa tidak diterapkannya akuntansi secara optimal pada sebagian besar UKM dikarenakan pengetahuan keuangan dan akuntansi yang dimiliki pelaku usaha masih belum memadai. Oleh karena itu, perlu dilakukan upaya-upaya untuk meningkatan pemahaman pengetahuan keuangan dan akuntansi bagi pelaku usaha.

Puspitaningtyas (2013b) mengemukakan bahwa pelaku UKM dalam menjalankan usahanya cenderung tanpa mengandalkan informasi akuntansi dan pengelolaan kas yang benar, sehingga tidak dapat mengetahui secara pasti kondisi keuangan usahanya. Keputusan yang diambil hanya berdasarkan pada intuisi bisnis, dan bukan berlatar pertimbangan informasi akuntansi.

Puspitaningtyas (2015b) menyebutkan bahwa pelaku UKM sebenarnya telah memiliki pengetahuan tentang akuntansi, akan tetapi mereka cenderung masih menjadikan kerumitan sebagai alasan untuk tidak melakukan pencatatan akuntansi dalam pengelolaan keuangannya. Dimana kerumitan yang dihadapi tidak sebanding dengan skala usahanya yang dinilai masih relatif kecil. Oleh karena itu, perlu mengubah mindset bagi pelaku UKM untuk membiasakan diri melakukan pencatatan akuntansi dalam pengelolaan keuangannya, sehingga dapat meningkatkan kualitas keputusan usaha yang didasarkan pada informasi akuntansi sebagai cerminan pencapaian kinerja usahanya.

Hasil analisis studi ini dan beberapa studi terdahulu telah menunjukkan bahwa pengelolaan keuangan berbasis akuntansi penting untuk dilakukan oleh pelaku usaha (khususnya pelaku UKM), karena akan memberikan manfaat bagi keberlanjutan usahanya dan meningkatkan daya saing. Dengan demikian upaya pembudayaan pengelolaan keuangan berbasis akuntansi bagi pelaku UKM harus terus dilakukan secara berkelanjutan. Oleh karena itu, pemerintah harus mempertimbangkan untuk terus menyusun program pelatihan dan pendampingan secara berkesinambungan dalam rangka pembudayaan pengelolaan keuangan berbasis akuntansi bagi pelaku usaha (khususnya pelaku UKM). Program pelatihan dan pendampingan yang dimaksudkan adalah berkaitan dengan kegiatan peningkatan kemampuan pengelolaan keuangan berbasis akuntansi bagi pelaku usaha, baik berupa pelatihan, sosialisasi, workshop, maupun pendampingan. Ketika pengetahuan dan pemahaman telah meningkat, maka tahap selanjutnya adalah mendorong atau memotivasi pelaku usaha untuk memiliki kemauan dan kemampuan menerapkan akuntansi dalam pengelolaan keuangan usahanya, salah satu indikatornya adalah ketersediaan laporan keuangan secara periodik atas usaha yang dijalankan oleh pelaku usaha (pelaku UKM).

\section{PENUTUP}

Berdasarkan hasil analisis dan pembahasan dapat disimpulkan bahwa pengelolaan keuangan berbasis akuntansi dapat memberikan manfaat bagi pelaku UKM untuk mengetahui kondisi keuangan usaha, mengatur dan mengontrol keseluruhan transaksi keuangan yang terjadi di sepanjang keberlangsungan usahanya. Pelaku usaha harus 
membiasakan (membudayakan) untuk menerapkan pengelolaan keuangan berbasis akuntansi, setidaknya melakukan pencatatan akuntansi yang paling sederhana. Pengetahuan mengenai akuntansi memegang peranan penting bagi pelaku usaha dan menjadi modal dasar dalam pengelolaan usaha dari sisi keuangan.

Implikasi dari hasil tersebut, bahwa sekadar memiliki pengetahuan tentang pengelolaan keuangan belum cukup bagi pelaku usaha untuk melangsungkan usahanya. Akan tetapi, dibutuhkan tekad bagi pelaku usaha untuk mau dan mampu menerapkan pengetahuan keuangan yang dimiliki sehingga dapat mengelola keuangan usahanya secara efektif. Pelaku usaha harus membiasakan atau membudayakan pengelolaan keuangan berbasis akuntansi. Proses akuntansi terdiri dari pencatatan, penggolongan atau pengklasifikasian, pelaporan, dan analisis informasi keuangan sehingga dapat diketahui kondisi keuangan usaha secara pasti. Pembudayaan pengelolaan keuangan berbasis akuntansi akan memberikan manfaat bagi pelaku usaha untuk menjalankan usahanya sehingga tetap dapat terintegrasi pada kegiatan bisnisnya dalam jangka panjang. Oleh karena itu, bagi pemerintah penting untuk mengoptimalkan perannya untuk mendorong peningkatan kemampuan pelaku usaha dalam pengelolaan keuangan usaha berbasis akuntansi.

\section{DAFTAR RUJUKAN}

Arifin, A.Z., Kevin, dan Siswanto, H.P. (2017) "The Influence of Financial Knowlegde, Financial Confidence, and Income on Financial Behavior among the Workforce in Jakarta". Proceeding, The 14th UBAYA International Annual Symposium on Management.

Apak, S., Erol, M., and Atmaca, M. (2012) "Accounting Measures to be Taken for the Enterprises in Difficulty During Times of Economic Crisis: A Study on Small and Medium-Sized Enterproses (SMEs)". African Journal of Business Management, 6 (23), 6832-6844.

Astuti, D.S.P. (2010) "Perlunya Penerapan Sistem Akuntansi pada Usaha Kecil Menengah". Jurnal Ekonomi dan Kewirausahaan, 10 (2), 152-163.

Aurora. (2013) "History and Challenges of Develpoments in the Sector of SMEs in Albania". Valahian Journal of Economic Studies, 4 (18), 45-52.

Chiou, B. (2011) "Which Types of Management Accounting System Information can be used to Respond Adequately to Environmental Uncertainty? The Effects of User Participation and Tolerance of Ambiguity". African Journal of Business Management, 5 (34), 13293-13301.

Denisa. (2012) "Features of the Accounting Information Users within the Small and Medium Companies (SMC)". Valahian Journal of Economic Studies, 3 (17), 7-12.

Ediraras, D.T. (2010) “Akuntansi dan Kinerja UKM". Jurnal Ilmiah Ekonomi Bisnis, 15 (2), 152-158.

Hira, T.K. (2009) Personal Finance: Past, Present and Future. Networks Financial Institute at Indiana State University, 2009-PB-10. http://ssrn.com/abstract=1522299.

Inn, J.T.J., Dumay, J., and Kokubu, K. (2015) “A Critical Examination of Implementing Government Sponsored Intellectual Capital Management and Reporting Programs for Small and Medium Enterprises". VINE, 45 (2), 214-238.

Karina, R. (2014) "Analisis Persepsi Manfaat Akuntansi dan Kebutuhan Informasi Akuntansi Bagi Pelaku UMKM (Usaha Mikro, Kecil dan Menengah) di Kota 
Pontianak". Jurnal Kajian Ilmiah Akuntansi Fakultas Ekonomi UNTAN (KIAFE), 3 (4).

Kaveh, D., Bamipour, E.M., Far, M.S., and Far, M.S. (2015) "The Relationship between Knowledge Management and Competitive Advantage: A Case Study in Small and Medium-Sized Companies in the Packaging Industry of Khorasan Razavi”. European Online Journal of Natural and Social Sciences, 4 (1), 650-659.

Kim, J., Lipka, R., and Sami, H. (2012) "Portfolio Performance and Accounting Measures of Earnings: an Alternative Look at Usefulness". Rev Quant Finan Acc, 38, 87-107.

Laurinkeviciute, A., and Stasiskiene, Z. (2011) "SMS for Decision Making of SMEs". Clean Techn Environ Policy, 13, 797-807.

Lohr, M. (2012) "Specificities of Managerial Accounting at SMEs: Case Studies from the German Industrial Sector". Journal of Small Business and Entrepreneurship, 25(1), 35-56.

Maseko, N., and Manyani, O. (2011) "Accounting Practices of SMEs in Zimbabwe: An Investigative Study of Record Keeping for Performance Measurement (A Case Study of Bindura)". Journal of Accounting and Taxation, 3 (8), 171-181.

Pinasti (2007) "Pengaruh Penyelenggaraan dan Penggunaan Informasi Akuntansi terhadap Persepsi Pengusaha Kecil atas Informasi Akuntansi: Suatu Riset Eksperimen”. Jurnal Riset Akuntansi, 10 (3), 321-331.

Puspitaningtyas, Z. (2012) "Relevansi Nilai Informasi Akuntansi dan Manfaatnya bagi Investor". Ekuitas: Jurnal Ekonomi dan Keuangan, 16 (2), 164-183.

(2013a) "Pola Pengelolaan Kas bagi Pelaku UKM Berdasarkan Orientasi

Entrepreneurial". Jurnal Entrepreneur dan Entrepreneurship, 2 (1), 93-100.

(2013b) "Perilaku Investor dalam Pengambilan Keputusan Investasi di Pasar

Modal". Prosiding Seminar Nasional \& Call for Paper Forum Manajemen Indonesia (FMI) Ke-5, Pontianak.

(2015a) Prediksi Risiko Investasi Saham: Decision Usefulness Approach.

Yogyakarta: Griya Pandiva.

(2015b) "Pemanfaatan Informasi Akuntansi Untuk Pengambilan Keputusan

Bisnis Bagi Pelaku Usaha Kecil dan Menengah". Prosiding Seminar Nasional Riset

Terapan 2015 (SENASSET 2015), Serang.

- (2016) "Mengelola Risiko Usaha Bagi Pelaku UKM dalam Bingkai

Perencanaan Keuangan". Prosiding Seminar Nasional Kewirausahaan \& Inovasi

Bisnis VI, Jakarta.

(2017) "Manfaat Literasi Keuangan Bagi Business Sustainability". Prosiding Seminar Nasional Kewirausahaan dan Inovasi Bisnis VII, Yogyakarta.

Putra, H.A., dan Kurniawati, E.P. (2012) "Penyusunan Laporan Keuangan untuk Usaha Kecil dan Menengah (UKM) berbasis Standar Akuntansi Keuangan Entitas Tanpa Akuntabilitas Publik (SAK ETAP)". Proceeding Call for Paper Pekan Ilmiah Dosen FEB-UKSW, Salatiga.

Rudiantoro, R. dan Siregar, S.V. (2011) "Kualitas Laporan Keuangan UMKM serta Prospek Implementasi SAK ETAP". Simposium Nasional Akuntansi XIV, Aceh.

Salazar, A.L, Soto, R.C., and Mosqueda, R.E. (2012) "The Impact of Financial Decisions and Strategy on Small Business Competitiveness". Global Journal of Business Research, 6 (2), 93-103.

Schaltegger, S., Ludeke-Freund, F., and Hansen, E.G. (2012) "Business Cases for Sustainability: The Role of Business Model Innovation for Corporate 
Sustainability". International Journal of Innovation and Sustainable Development, 6 (2).

Suryani, S., Nuraini, E., Kadir, E.A., dan Ramadhan, S. (2017) "Analysis of Financial Literacy in Micro Business in Pekanbaru Indonesia". Proceeding, The 14th UBAYA International Annual Symposium on Management.

Turyahebwa, A., Sunday, A., and Ssekajugo, D. (2013) "Financial Management Practices and Business Performance of Small and Medium Enterprises in Western Uganda". African Journal of Business Management, Vol. 7 (38), 3875-3885.

Williams, B.R., and O'Donovan, G. (2015) 'The Accountants' Perspective on Sustainable Business Practices in SMEs". Social Responsibility Journal, 11 (3), 641-656.

Young, L., Schaffers, L., and Bruwer, J. (2012) "South African Informal Businesses Sustainability in the Cape Town Central Business District: The Power of Internal Financial Controls". African Journal of Business Management, 6 (45), 1132111326. 